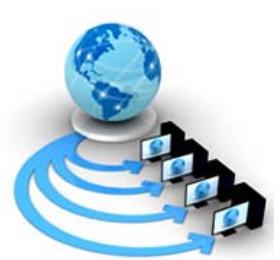

Volume 8, No. 9, November-December 2017

International Journal of Advanced Research in Computer Science

RESEARCH PAPER

\author{
Available Online at www.ijarcs.info
}

\title{
DEVELOPING GIS WEB-PORTAL FOR COLLEGE INFORMATION SYSTEM USING FREE AND OPEN SOURCE SOFTWARE
}

\author{
Dipak Y. Gotey \\ Department of Computer Science and IT \\ Dr. Babasaheb Ambekar Marathwada Univerity \\ Aurangabad, Maharashtra India
}

\author{
Karbhari V. Kale \\ Department of Computer Science and IT \\ Dr. Babasaheb Ambedkar Marathwada University \\ Aurangabad, Maharashtra India
}

\begin{abstract}
There are many courses available after completion of secondary education in India. These courses are provided by colleges which are affiliated to universities or these can be standalone institutes. The decision to choose from these courses depends on many criteria. These criteria include interest of student, job opportunities, cost, location etc. Based on the need of society, a web portal is designed that will help student to make good decision about their education.
\end{abstract}

Keywords: Higher education, Web portal, GIS, Information System, Open Government Data

\section{INTRODUCTION}

India is diverse country with many cultures, languages, traditions. Roots of education are found in India with the oldest universities like Nalanda and Takshashila. Education plays vital role in human development. Post-Independence of India the policies about education are mainly governed by the central government. Education is on "concurrent list" that means Centre and state government can make laws that govern education system in India.[1] In last two and half decade India has shown very positive signs of development including education. The number of student going for higher education is increasing day by day. [2] Student are getting more selective about the carrier they want to make future in. Also there has been drastic change in the mode of information interchange over time. Now with internet and Smartphone one can possibly get any information round the world through website. Unfortunately there is no reliable system that can give information about the courses of education available for an aspirant student. So therefore a need is felt for a website that will provide reliable, assured information about various courses and colleges along with the faculty, cost, student enrollment and result. This paper is about website that is designed to cater the requirement of student which will guide them in taking good decision about their higher education by giving details of the college information across India.

\section{LITERATURE REVIEW AND RELATED WORK}

Work has been done to map planning [3], marketing [4], retail [5], transportation [6], traffic [7], tourism [8], natural resources [9], real estate [10], agriculture [11] and healthcare [12] on the map and giving details about the facilities available there. On similar lines there are websites which give information about the colleges.[13][14][15] These sites giving information about the popular colleges from few cities of India also the information provided is very less. So for user it was necessary to visit multiple sites to search for information he is looking for. Also the address of the college was textual and exact location of the college cannot be found unless user visit the college. Google map provides the location of few of the colleges and not all of the colleges. Also in few cases the location mapped on google map is found to be misleading because of wrongly tagged marker.

\section{Proposed SySTEM}

From year 2010-11 Ministry of Human Resource Development is collecting information about the colleges that are providing higher education in India under All India Survey of Higher Education (AISHE). The information includes courses, programs, faculty, student count, Infrastructure, exam result, scholarships etc. This information is provided by corresponding college. The source of information about the college is college management so this information is highly reliable and accurate.[2] After instigation of National Data Sharing and Accessibility Policy[20] the data collected in AISHE is made available to public under open government data on website www.data.gov.in.[16] This data is present in human and machine readable format. For machine readable format API are provided and also same data is provided in CSV file format. This data forms the base of the website. The website technologies which are commonly used worldwide are put to work for this project. These web-technologies include Linux operating system, Apache web server, MySQL database and php server scripting language.[21] Google map javascript API are used for geolocation of colleges. Geotagging and finding route to the college from user location is also performed using google map JavaScript API. These technologies are free and open source. Also lot of help is available online through community sites, blogs and tutorials which is not the case with other paid and licensed software.

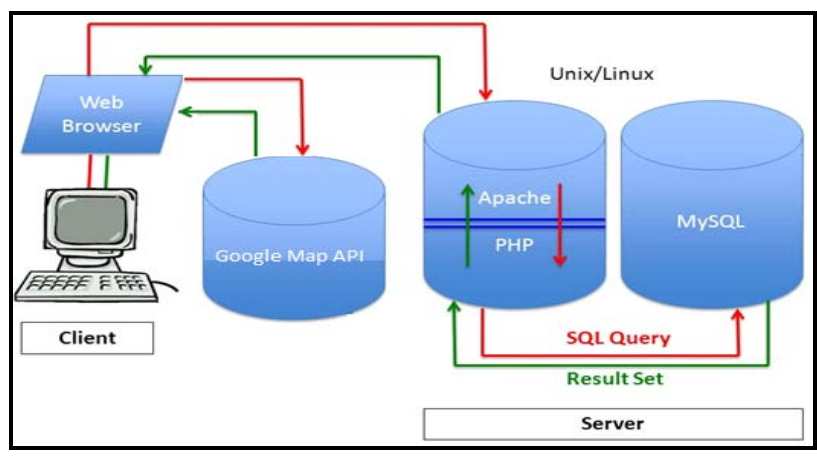

Figure 1. System Architecture 


\section{IMPLEMENTATION}

The data in csv format is downloaded from open government data website www.data.gov.in. This data is uploaded to mysql database using load data in file statement.

LOAD DATA INFILE Syntax[17]

LOAD DATA [LOW PRIORITY | CONCURRENT]

[LOCAL] INFILE 'file name'

[REPLACE | IGNORE]

INTO TABLE tbl name

[PARTITION (partition name [, partition name] ...)]

[CHARACTER SET charset name]

[ \{FIELDS | COLUMNS\}

[TERMINATED BY 'string']

[[OPTIONALLY] ENCLOSED BY 'char']

]

[ESCAPED BY 'char']

[LINES

[STARTING BY 'string']

[TERMINATED BY 'string']

]

[IGNORE number $\{$ LINES | ROWS $\}$ ]

[(col name or user var

[, col name or user var] ...)]

$[$ SET col name $=\{\operatorname{expr} \mid$ DEFAULT $\}$,

[, col name $=\{\operatorname{expr} \mid$ DEFAULT $\}] \ldots]$

The basic information of college included latitude and longitude data of colleges. This latitude and longitude data is used for geolocation and geotagging of colleges. For the usage of Google Map JavaScript API user key is generated. The free use is restrictive but one barely crosses the usage limit.[19] In case when the free usage limit is not sufficient paid usage service can be opted. Big Bang Model framework is used to structure, plan, and control the process of developing this Geographical Information system. A Geographical Information System (GIS) is a computer system for capturing, storing, querying, analyzing and displaying geospatial data. Geospatial data means the data which describes the location and characteristics of that location [18]

Accessing the Data.

1. The home page is College Search page.

2. The college can be searched by entering keywords.

3. Or by selecting filtering parameters

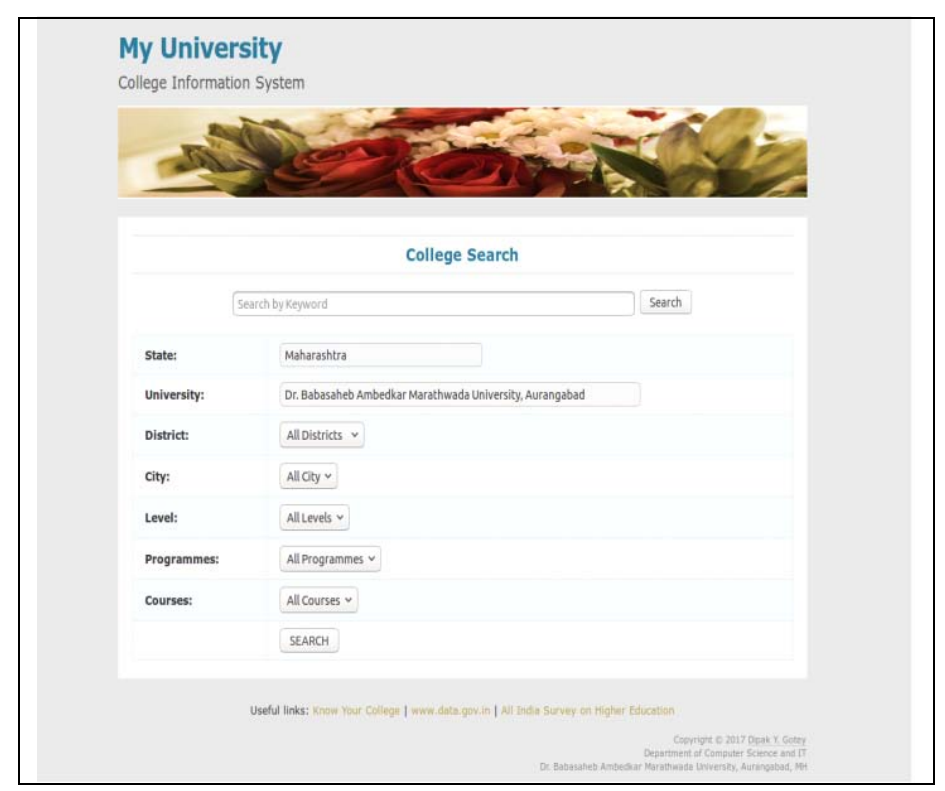

Figure 2. College Search Page
Search result will be shown on the map with marker and List of colleges matching given filter option.

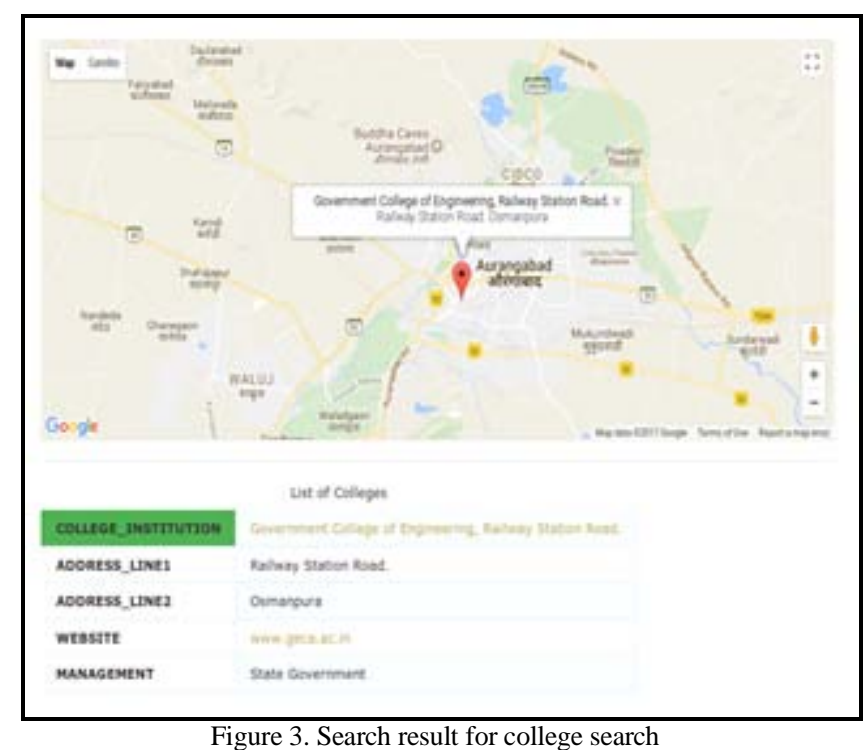

The link on the college name will redirect to college details. College details include the Basic Information that is id, survey year, state, college institution, address line1, address line2, city, district, pin code, website, area in acre, construct in sqmt, year of establishment, affiliate university, other affiliated university id, statutory body id, other statutory body, year of affiliation, location, latitude, longitude, type, autonomous, has diploma courses, management, specialized, evening, specialty, other specialty, girl exclusive, staff quarter available, non teaching staff, teaching staff, total, student hostel available, hostel count. The other menu items are Courses, Faculty, Student Count, Result, Infrastructure, and Direction. Regular Courses Details includes level, program, discipline, discipline group category, discipline group, intake, admission criterion, duration year, duration month, and system. Teaching Staff Details includes department name, designation, total persons, designation sanctioned strength, in position direct, in position cas, number of $\mathrm{PhD}$ teachers. Student Count Details includes level, program, discipline group, discipline, year, total persons Examination Result includes id, survey year, name, course mode, course level, program id, program, discipline group id, broad discipline group, discipline, appeared female, appeared total, passed female, passed total, first class passed female, first class passed total. Infrastructure Details includes id, survey year, name, playground, auditorium, theatre, library, laboratory, conference hall, health center, gymnasium fitness center, indoor stadium, common room, computer center, cafeteria, guest house, number of playgrounds, number of auditoriums, number of theatres, number of libraries, number of laboratories, number of conference halls, number of health centers, number of gymnasium fitness centers, number of indoor stadiums, number of common rooms, number of computer centers, number of cafeteria, number of guest houses, separate room for girls, number of separate rooms for girls, solar power generation, connectivity nkn, connectivity nmeict, number of books, number of journals, campus friendly, grievance redressal mechanism, vigilance cell, opportunity cell.

Direction includes the route to college from user current location. 


\section{Result}

User is able to search college with keyword. User is able to find colleges located in particular city, Colleges offering particular course of interest. User is able to get details about the courses offered by any college. User is able to reach to college following the route shown on google map. These details will help user by giving the information they are looking for.

\section{CONCLUSION AND DISCUSSION}

College information system will help student to identify colleges in the region. It will help them to select best college based on the facilities available in the college. The system will guide the traveler to reach its destination college by providing the shortest route from its known location. The web site can be accessed from handheld Smartphone with ease.

There is huge scope to add many more functionalities to the given system. The project will grow as per the requirements needed. The system will remain in continuous development phase as the technologies advances with the time and data gets updated.

\section{ACKNOWLEDEMENT}

I am thankful to Professor K. V. Kale for suggestions and guidance. I would like to acknowledge and thanks to University Grants Commission (UGC), India for granting UGC SAP (II) DRS Phase-I \& Phase-II F. No. 3-42/2009 \& 4-15/2015/DRS-II Geospatial Technology Research Laboratory facility and Department of Computer Science and Information Technology, Dr. Babasaheb Ambedkar Marathwada University, Aurangabad, Maharashtra, India.

\section{REFERENCES}

[1] http://www.going-global

edu.in/educationsystem.html (accessed on 19-Nov-2017)

[2] AISHE Report 2015-16 http://mhrd.gov.in/sites/upload files/mhrd/files/statistics/AISHE2015-16.pdf

[3] R. Mari, L. Bottai, C. Busillo, F. Calastrini, B. Gozzini and G. Gualtieri, "A GIS-Based Interactive Web Decision Support System for Planning Wind Farms in Tuscany (Italy),” Renewable Energy, Vol. 36, No. 2, 2011, pp. 754-763.

[4] A. M. Ozimec, M. Natter and T. Reutterer, "Geographical Information Systems-Based Marketing Decisions: Effects of Alternative Visualizations on Decision Quality,” Journal of Marketing, Vol. 74, No. 6, 2010, pp. 94-110.

[5] A. Okabe and K. Okunuki, "A Computational Method for Estimating the Demand of Retail Stores on a Street Network and Its Implementation in GIS,” Transactions in GIS, Vol. 5, No. 3, 2001, pp. 209-220.

[6] A. K. Ziliaskopoulos and S. T. Waller, "An Internet-Based Geographic Information System That Integrates Data, Models and Users for Transportation Applications," Transportation Research Part C, Vol. 8, No. 1-6, 2000, pp. 427-444.

[7] F. Xie, "Design and Implementation of Highway Management System Based WebGIS,” Journal of Networks, Vol. 5, No. 12, 2010, pp. 1389-1392.

[8] S. P. Singh, J. Sharma and P. Singh, "A Geo-Referenced Information System for Tourism (GeoRIST)," International Journal of Geomatics and Geosciences, Vol. 2, No.2, 2011, pp. 456-464.

[9] P. S. Singh, D. Chutiya and S. Sudhakar, "Development of a Web Based GIS Application for Spatial Natural Resources Information System Using Effective Open Source Software and Standards,” Journal of Geographic Information System, Vol. 4, No. 3, 2012, pp. 261-266.

[10] T. Q. Zeng and Q. Zhou, "Optimal Spatial Decision Making Using GIS: A Prototype of a Real Estate Geographical Information System (REGIS)," International Journal of Geographical Information Science, Vol. 15, No. 4,2001, pp. 307-321.

[11] T. Oswari, E. S. Suhendra, E. Haryatmi and F. Agustina,"Prototype Geographic Information Systems Mapping of Crop Products Featured Local,” Journal of Geographic Information System, Vol. 5, No. 3, 2013, pp. 193197.

[12] B. Evans and C. E. Sabel, “Open-Source Web-Based Geographical Information System for Health Exposure Assessment,” International Journal of Health Geographics, Vol. 11, 2012, p. 2.

[13] http://www.studyinindia.org/ (accessed on 19-Nov-2017)

[14] www.shiksha.com (accessed on 19-Nov-2017)

[15] http://college-search.bamu.ac.in/ (accessed on 19-Nov-2017)

[16] "Ministry of Human Resource Development, 2017, All India Survey on Higher Education - 2015-16, Open Government Data Platform India, https://data.gov.in/catalog/all-indiasurvey-higher-education-2015-16. Published under National Data Sharing and Accessibility Policy (NDSAP) : https://data.gov.in/sites/default/files/NDSAP.pdf."

[17] https://dev.mysql.com/doc/refman/5.7/en/load-data.html

[18] Kang-Tsung chang, "Introduction to Geographic information system (Fourth Edition)”, Tata McGraw Hill Private Limited.

[19] https://developers.google.com/maps/documentation/javascript/ get-api-key (accessed on 12-may-2017)

[20] Open Data Policy of India https://data.gov.in/sites/default/files/NDSAP.pdf

[21] https://w3techs.com/ (accessed on 19-Nov-2017) 